\title{
N- and KRAS Mutations in Primary Testicular Germ Cell Tumors: Incidence and Possible Biological Implications
}

\author{
Robert A. Olie, Leendert H.J. Looijenga, Lucie Boerrigter, Bert Top, Sjoerd Rodenhuis, An Langeveld, \\ Maarten P. Mulder, and J. Wolter Oosterhuis \\ Laboratory of Experimental Patho-Oncology, Dr. Daniel den Hoed Cancer Center (R.A.O., L.H.J.L., J.W.O.); Department of Cell \\ Biology and Genetics, Erasmus University (A.L., M.P.M.), Rotterdam; Division of Experimental Therapy, The Netherlands Cancer \\ Institute, Amsterdam (L.B., B.T., S.R.), The Netherlands
}

\begin{abstract}
Recently, conflicting results have been reported on the incidence of RAS mutations in primary testicular germ cell tumors of adults (TGCTs). In four studies a low incidence of mutations (less than 15\%) in a variety of TGCTs or derived cell lines was found, whereas in two other studies a high incidence of $N$ - or KRAS mutations (over 40\%) was shown. A total of 62 testicular seminomas (SE) and 34 nonseminomatous TGCTs (NS) were studied thus far. The largest series consisted of 42 TGCTs, studied on paraffin embedded tissue. We present the results of analysis for the presence of $N$-and KRAS mutations, in codons 12, 13, and 61 , in snap frozen samples of 100 primary TGCTs, comprising 40 SE and 60 NS. Using the polymerase chain reaction (PCR) and allele specific oligonucleotide hybridization (ASO), mutations were found in five SE (three in NRAS and two in KRAS, all codon 12), and in one NS (KRAS, codon 12). To exclude underestimation of the incidence of RAS mutations in TGCTs due to the presence of an excess of wild type alleles in the analyzed sample, a PCR technique preferentially amplifying KRAS alleles with a mutation in codon 12 was applied to all SE. This approach, allowing a 250 times more sensitive assay, resulted in the detection of only one additional SE with a mutation. Based on a critical analysis of published data and on our results from the largest series of frozen samples investigated thus far, we conclude that $\mathrm{N}$ - or KRAS mutations are rare and apparently not essential for initiation or progression of TGCTs. Genes Chromosom Cancer 12:110-116 (1995). (c) 1995 Wiley-Liss, Inc.
\end{abstract}

\section{INTRODUCTION}

The p21 proteins encoded by $N$-, $H$ - and $K R A S$ are involved in signal transduction from activated receptors in the cellular membrane to the nucleus. Mutations in these genes, particularly those in codons 12,13 , and 61 , cause a decrease in intrinsic GTPase activity, leading to constitutive activation of the encoded protein (Rodenhuis, 1992; McCormick, 1993). RAS mutations have been detected in a wide variety of human neoplasms, although with varying incidence (Rodenhuis, 1992), and are considered to represent only one of many events in the multistep process of transformation (Kumar et al., 1990).

A low incidence of KRAS codon 12 mutations (less than 15\%) has been found in all studies on human primary testicular germ cell tumors (TGCTs) (Mulder et al., 1989; Ganguly et al., 1990; Moul et al., 1992; Ridanpää et al., 1993). In contrast, conflicting data have been reported for $N R A S$. One study showed mutations at codon 12 or 61 in 13 of 20 seminomas (SE) and two of three nonseminomatous TGCTs (NS) (Ganguly et al., 1990). Another study, comprising only SE, revealed $N R A S$ codon 61 mutations in four of 14 tumors (Mulder et al., 1989). No mutations were found in NRAS codons 12 or 61 in two studies, comprising $28 \mathrm{SE}$ and 31 NS (Moul et al., 1992;
Ridanpää et al., 1993). A consistent finding is the absence of mutations in NRAS codon 13; HRAS codon 12,13, and 61; and $K R A S$ codons 13 and 61 in TGCTs and derived cell lines (Mulder et al., 1989; Dmitrovsky et al., 1990; Ganguly et al., 1990; Tesch et al., 1990; Moul et al., 1992; Ridanpää et al., 1993).

Several factors may explain the varying findings on the incidence of RAS mutations in TGCTs. Besides possible geographical influences (Rodenhuis, 1992), technical factors related to the method of fixation of the tissue samples, frozen (Mulder et al., 1989; Ganguly et al., 1990; Ridanpää et al., 1993) versus paraffin embedded (Moul et al., 1992), might be involved. In addition, the applied polymerase chain reaction and allele specific oligonucleotide hybridization (PCR/ASO) might underestimate the incidence of mutations when an excess of wild type alleles is present, since it allows detection of one mutant among 40 wild type alleles (Slebos et al., 1992). This could especially be important for $S E$, which may contain a high percentage (over $80 \%$ ) of nonmalignant cells (Mostofi et al.,

Received June 10, 1994; accepted August 10, 1994.

Address reprint requests to R.A. Olie, Laboratory of Experimental Patho-Oncology, Dr. Daniel den Hoed Cancer Center, Groene Hilledijk 301, 3075 EA Rotterdam, The Netherlands. 
1987; Mulder et al., 1989). 'To overcome this problem, Mulder et al. (1989) used suspensions of SE nuclei sorted on the basis of their aneuploid DNA content. An alternative is the use of a PCR technique which preferentially amplifies mutant alleles (mutant-enriched PCR, MEPCR). It has been shown by Kahn et al. (1991) that this approach allows detection of one mutant among 10,000 wild rype alleles using ASO (MEPCR/ASO).

We have studied snap frozen samples of 100 primary TGCTs, comprising $40 \mathrm{SE}$ and $60 \mathrm{NS}$, using PCR/ASO for detection of $N$ - and $K R A S$ codons 12 , 13 , and 61 mutations. In addition, MEPCR/ASO for $K R A S$ codon 12 was used on all SE.

\section{MATERIALS AND METHODS}

\section{Tumor Samples}

One hundred primary TGCTs and adjacent parenchyma (when present) were collected at the operation theatres of collaborating hospitals. After frozen section diagnosis (using a haematoxylin and eosin stained tissue section), representative parts of tumor and adjacent parenchyma were snap frozen in liquid $\mathrm{N}_{2}$. Typing according to the WHO classification (Mostofi et al., 1987) was based on histology and immunohistochemical analyses of expression of placental-like alkaline phosphatase (PLAP), alpha fetoprotein (AFP), human chorionic gonadotropin (hCG) (Dako, Glostrup, DK), and cytokeratins 8 and 18 (Beckton Dickinson, San Jose, CA) using representative paraffin and frozen tissue sections, as described (Oosterhuis et al., 1989).

Frozen samples destined for DNA extraction were microscopically checked for the presence of tumor cells. In addition, suspensions of cell nuclei were prepared from $25 \mathrm{NS}$ samples. These were stained with propidium iodide and analysed by flow cytometry to determine the fractions of aneuploid and diploid cells as described by Mulder et al. (1989).

\section{DNA Extraction}

DNA was extracted from snap frozen tumor samples, as described (Maniatis et al., 1982). From each sample three $10 \mu \mathrm{m}$ thick sections were collected in $100 \mu$ l lysis buffer $(10 \mathrm{mM}$ Tris, $400 \mathrm{mM}$ $\mathrm{NaCl}, 2 \mathrm{mM}$ EDTA, $1 \%$ SDS, $10 \mu \mathrm{g} / \mathrm{ml}$ proteinase $\mathrm{K}$ (Sigma, St. Louis, MO), pH 8.2) and lysed overnight at $37^{\circ} \mathrm{C}$. Subsequently the samples were extracted twice with an equal volume of phenol/chloroform. After precipitation in ethanol/sodium acetic acid, the DNA pellet was dissolved in 10 $\mathrm{mM}$ Tris, $0.1 \mathrm{mM}$ EDTA to a final concentration of approximately $0.5 \mu \mathrm{g} / \mu \mathrm{l}$. From each sample 0.5 $\mu l$ (approx. $250 \mathrm{ng}$ DNA) was used for PCR. The agarose gel electrophoresis performed to confirm the presence of PCR products, as described in the next section, was also used to confirm the presence of comparable amounts of DNA in each PCR. Matched, carcinoma-in situ containing parenchyma of tumors with a $R A S$ mutation was also studied, when available $(n=4)$.

\section{Polymerase Chain Reaction}

Amplification was performed in a reaction mixture which consisted of buffer $(50 \mathrm{mM} \mathrm{KCl}, 2.5$ $\mathrm{mM} \mathrm{MgCl} 2,10 \mathrm{mM}$ Tris- $\mathrm{HCl}(\mathrm{pH} 8.0), 10 \mathrm{mM}$ $\mathrm{NaCl}, 0.01 \mathrm{mM}$ EDTA, $0.5 \mathrm{mM}$ DTT, $0.1 \%$ Triton X-100) (Promega, Madison, WI), $0.2 \mathrm{mM}$ of each nucleotide (dATP, dTTP, dCTP, dGTP) (Pharmacia, Woerden, the Netherlands), $1 \mathrm{U}$ Taq polymerase (Promega), $0.5 \mu \mathrm{M}$ of both sense and anti-sense primer in a total volume of $50 \mu \mathrm{l}$. Four different primer sets, described by Verlaan-de Vries et al. (1986), were used to amplify the KRAS 12 and 13, KRAS 61, NRAS 12 and 13, and NRAS 61 regions. The reaction mixture was covered with paraffin oil. Samples were placed in a Thermal Cycler (Perkin-Elmer, Norwalk, VA) and heated to $94^{\circ} \mathrm{C}$ for $1 \mathrm{~min}$. The PCR included 35 cycles of denaturation at $94^{\circ} \mathrm{C}$ for $30 \mathrm{sec}$, annealing at $54^{\circ} \mathrm{C}$ for $30 \mathrm{sec}$, and extension at $72^{\circ} \mathrm{C}$ for $1 \mathrm{~min}$. Finally, the samples were kept at $72^{\circ} \mathrm{C}$ for 2 min and subsequently stored at $4^{\circ} \mathrm{C}$ till further analysis. All samples were tested for the presence (or absence, in the negative control, containing $\mathrm{H}_{2} \mathrm{O}$ instead of DNA) of the desired fragment by agarose gel electrophoresis and ethidium-bromide staining, using 4 $\mu l$ of the PCR mixture.

\section{Mutant-Enriched Polymerase Chain Reaction for KRAS Codon 12}

Amplification was performed in a reaction mixture which consisted of buffer $\left(3.5 \mathrm{mM} \mathrm{MgCl}_{2}, 15\right.$ $\mathrm{mM}\left(\mathrm{NH}_{4}\right)_{2} \mathrm{SO}_{4}, 60 \mathrm{mM}$ Tris- $\left.\mathrm{HCl} \mathrm{pH} 8.4\right), 0.2$ $\mathrm{mM}$ of each nucleotide (dATP, dTTP, dCTP, dGTP), $1.5 \mathrm{U}$ Taq polymerase, $1 \mu \mathrm{M}$ of both sense and anti-sense primer in a final volume of 50 $\mu l$. Using a mismatched sense primer (introducing a $B s t \mathrm{~N} 1$ restriction site in the wild type allele) together with an antisense primer (Kahn et al., 1991), KRAS 12 regions were amplified. The samples were heated to $96^{\circ} \mathrm{C}$ for $5 \mathrm{~min}$, followed by one cycle at $96^{\circ} \mathrm{C}$ for $2 \mathrm{~min}, 55^{\circ} \mathrm{C}$ for $1 \mathrm{~min}$, and $73^{\circ} \mathrm{C}$ for $1 \mathrm{~min}$. During 24 cycles, the samples were brought to $96^{\circ} \mathrm{C}$ for $30 \mathrm{sec}, 55^{\circ} \mathrm{C}$ for $30 \mathrm{sec}$, and to 
$73^{\circ} \mathrm{C}$ for $1 \mathrm{~min}$. Each sample $(12.5 \mu \mathrm{l})$ was then digested overnight at $370^{\circ} \mathrm{C}$ to completion with $5 \mathrm{U}$ endonuclease $M v a 1$, an isoschizomer for $B s t \mathrm{~N} 1$ (Boehringer, Mannheim, Germany), in $26 \mu \mathrm{l}$ buffer $\mathrm{H}(50 \mathrm{mM}$ Tris-HCl, pH 7.5, $10 \mathrm{mM}$ $\mathrm{MgCl}_{2}, 100 \mathrm{mMNaCl}, 1 \mathrm{mM}$ dithioerythritol)(Boehringer, Mannheim, Germany). In a second round of PCR, under the same conditions as described above, except for the use of the mismatched sense primer and a nested antisense primer, only the uncleaved (mutated) fragments were amplified. To show the effect of mutant-enrichment the second PCR was also applied to undigested amplification product of the first PCR.

\section{Allele Specific Oligonucleotide Hybridization}

Paraffin oil was removed from the PCR-samples by extraction with diethyl ether. DNA was denatured at $96^{\circ} \mathrm{C}$ for $3 \mathrm{~min}$ and $1 \mu \mathrm{l}$ of PCR mixture from each sample was dotted on a dry Nytran-N membrane (Schleicher \& Schuell, Dassel, Germany), which had previously been soaked in $\mathrm{H}_{2} \mathrm{O}$ and $10 \times \mathrm{SSC}$, and air dried. DNA from previously characterized mutation-carrying samples was used as positive control. These controls were available for all KRAS 12 positions (Slebos et al., 1990) and for $K R A S 13$ position 1 and $K R A S 61$ position 3 (Oudejans et al., 1991). As negative control a sample of the PCR mixture without DNA was used. DNA was crosslinked to the membrane by exposure to UV light for $2 \mathrm{~min}$.

The $N$ - and KRAS 12 and 13 wild type alleles were detected by specific wild type probes, and identification of KRAS 12 mutations was performed using 6 specific probes after conventional PCR, and 6 after mutant-enriched PCR (Verlaan-De Vries et al., 1986; Kahn et al., 1991). Two mixtures of three probes (codon positions 1 and 2) were used for $K R A S 13$ and NRAS 12 and 13, while for KRAS 61 and NRAS 61 three mixtures of three mutation specific probes (for positions 1, 2, or 3 of the codons) were applied (Verlaan-De Vries et al., 1986). Five picomoles $(1 \mu \mathrm{l})$ of probe was endlabeled using 2.5 U T4 polynucleotide kinase (PNK) (Gibco BRL, Breda, the Netherlands) in $4 \mu 1$ reaction mix $(50 \mathrm{mM}$ Tris.HCl pH 7.6, $10 \mathrm{mM}$ $\mathrm{MgCl}_{2}, 5 \mathrm{mM}$ DTT, $0.1 \mathrm{mM}$ EDTA, $0.1 \mathrm{mM}$ spermidine, $10 \mu \mathrm{Ci}(1 \mu \mathrm{l}){ }^{32} \mathrm{P} \gamma$-ATP (Amersham, Den Bosch, the Netherlands). After incubation at $37^{\circ} \mathrm{C}$ for $30 \mathrm{~min}, 70 \mu \mathrm{l}$ of $10 \mathrm{mM}$ Tris $/ 0.1 \mathrm{mM}$ EDTA and $1 \mu \mathrm{l}$ tRNA were added and the mix was centrifuged through a Clontech-100 column (Clontech Laboratories, Palo Alto, CA).

All blots were soaked in aqua dest in separate hybridization tubes. The aqua dest was replaced by $2 \mathrm{ml}$ hybridisation mix ( $3 \mathrm{M}$ tetramethylammonium chloride, $50 \mathrm{mM}$ Tris pH 7.5, $5 \mathrm{mM}$ EDTA, $1 \%$ SDS, $1 \%(\mathrm{w} / \mathrm{v})$ milk protein (Protifar) (Nutricia, Zoetermeer, the Netherlands). After prehybridization for $60 \mathrm{~min}$ at $56^{\circ} \mathrm{C}, 20 \mu \mathrm{l}$ of labeled probe was added and hybridization was done for 1 hr at $56^{\circ} \mathrm{C}$. Blots were washed in hybridization mix without milk protein at $56^{\circ} \mathrm{C}$ for $30 \mathrm{~min}$, taken from the tubes, rinsed with $2 \times \operatorname{SSC}(0.3 \mathrm{M} \mathrm{NaCl}$, $0.03 \mathrm{M}$ sodium citrate, $\mathrm{pH} 7.0$ ), dried, and exposed overnight to an XomatAR film (Eastman Kodak, Rochester, NY) at $-70^{\circ} \mathrm{C}$. Subsequently, blots were washed at higher stringency in $5 \times$ SSPE $(50 \mathrm{mM}$ sodium phosphate, $0.9 \mathrm{M} \mathrm{NaCl}$, $5 \mathrm{mM}$ EDTA) $/ 0.1 \% \mathrm{SDS}$, for $30 \mathrm{~min}$, to remove any probe mismatched to the PCR product. In the $\mathrm{PCR} / \mathrm{ASO}$, temperature was kept at $57^{\circ} \mathrm{C}$ for $N R A S$ $61,59^{\circ} \mathrm{C}$ for $\operatorname{KRAS} 61,61^{\circ} \mathrm{C}$ for NRAS 12 and 13 , and $63^{\circ} \mathrm{C}$ for $K R A S 12$ and 13 , while the temperature was $61^{\circ} \mathrm{C}$ in the MEPCR/ASO for KRAS 12 . The blots were again rinsed with $2 \times$ SSC, dried, and exposed for 1 to 4 days, as described. Mutations could be detected comparing the dot signals obtained before (to verify the presence of PCR products) and after the stringent wash.

\section{Identification of Mutations}

The exact nature of the NRAS 12 mutations was revealed by a cycle sequencing protocol (Cycle Sequencing Kit, Perkin-Elmer Cetus, Norwalk, CT) using a ${ }^{32}$ P-labeled sense primer. In brief, the tumor samples were amplified in triplicate using conventional PCR. The PCR products were pooled and subjected to electrophoresis on a $2.5 \%$ preparative agarose gel. The fragments were excised from the gel and incubated with $6 \mathrm{U}$ agarase (Boehringer, Mannheim, Germany) for $1 \mathrm{hr}$ at $45^{\circ} \mathrm{C}$. The purified DNA fragments were ethanol precipitated at $-70^{\circ} \mathrm{C}$ for $15 \mathrm{~min}$ and dissolved in $25 \mu \mathrm{l}$ of sterile water. Twenty cycles of denaturation at $95^{\circ} \mathrm{C}(1 \mathrm{~min})$, annealing at $63^{\circ} \mathrm{C}(1.5 \mathrm{~min})$, and extension at $72^{\circ} \mathrm{C}(2 \mathrm{~min})$ were performed in a thermal cycler (Hybaid ${ }^{\mathrm{TM}}$, Teddington, United Kingdom). The sequencing reactions were analyzed on a denaturing $6 \%$ polyacrylamide sequencing gel at $60 \mathrm{~W}$ for $2.5 \mathrm{hr}$. The gel was exposed at $-70^{\circ} \mathrm{C}$ for $16 \mathrm{hr}$ as described above, with an intensifying screen.

\section{RESULTS}

Classification of the obtained tumors revealed 40 $\mathrm{SE}$ and $60 \mathrm{NS}$. The group of NS comprised 22 pure tumors (12 embryonal carcinomas [EC], four yolk sac tumors [YS], five teratomas [T] [both mature 


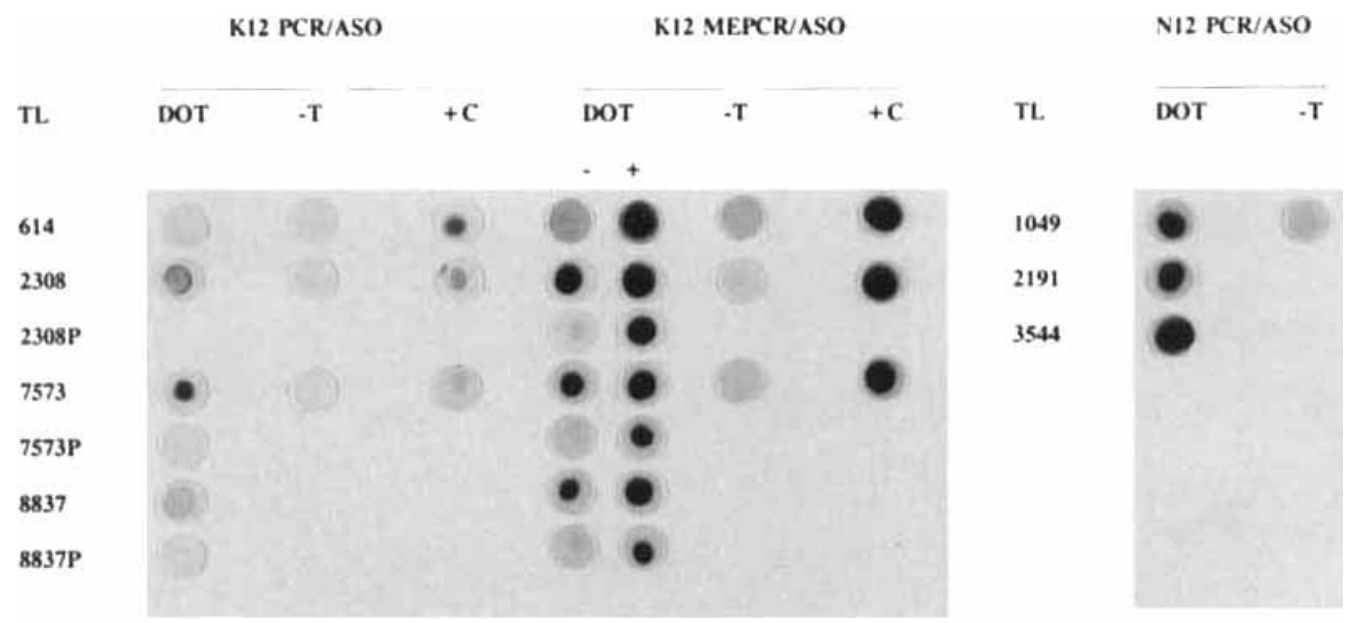

Figure 1. Dot blot signals (after high stringency wash) of all mutant tumors after amplification of the $N$ - or KRAS 12 region, using PCR/ASO or MEPCRASO. TL = tumor; $P=$ parenchyma adjacent to the tumor DOT = signal of the mutant tumor; $-T=$ signal of a representative mutation-negative tumor; $+C=$ signal of the corresponding positive

and immature] and one choriocarcinoma $[\mathrm{CH}]), 35$ tumors containing EC mixed with one or more other components (CH, SE, T, YS), two tumors containing $\mathrm{CH}$ and $\mathrm{T}$, and one tumor containing $\mathrm{T}$ and $\mathrm{YS}$.

A low incidence of codon 12 mutations was found in both $N$ - and $K R A S$, whereas no mutations in $N$ - or KRAS 13 or 61 were detected in any of the analyzed TGCTs. Three SE (TL1049, TL2191, and TL3544) were found with a mutation in NRAS 12, while two SE (TL7573, TL8837) and one NS (TL2308, containing EC, T, and YS) with a KRAS 12 mutation were detected (Fig. 1).

Using the PCR/ASO approach, mutations in some tumor samples might have remained undetected due to the presence of an excess of wild type alleles. Therefore suspensions of cell nuclei were prepared from 25 frozen NS samples, stained with propidium iodide, and analysed by flow cytometry to determine the fraction of aneuploid (tumor) and diploid (nontumor) cells. The fraction of aneuploid cells varied between 22 and $93 \%$, while 18 tumors contained more than $50 \%$ aneuploid cells.

It has previously been shown that in SE samples the fraction of nontumor cells can be greater than $90 \%$ (Mulder et al., 1989). We therefore decided to repeat the mutation analysis in our series of $\mathrm{SE}$ using MEPCR/ASO for KRAS 12. In this procedure mutant alleles are preferentially amplified, hereby allowing the detection of one mutant among 10,000 wild type alleles (Kahn et al., 1991). The analysis revealed one extra mutant SE (TL614). The previously detected mutations were confirmed, showing an intensified signal after MEPCR/ASO, com- control containing a GGT to GCT transition (for TL6|4), a GGT to TGT transition (for TL2308), or a GGT to CGT transition (for TL7573 and TL8837); - and + indicate MEPCR/ASO without, respectively, with Mval digestion of the product from the first PCR, resulting in mutant enrichment for the + condition.

pared to PCR/ASO and MEPCR/ASO without Mva 1 digestion (Figs. 1 and 2).

Parenchyma adjacent to a mutant tumor was available for TL614, TL2308, TL3544, TL7573, and TL8837. Only the parenchyma of TL614 did not contain carcinoma in situ (CIS), the precursor of all TGCTs (Skakkebæk et al., 1987) and therefore this sample was not studied further. In the parenchyma of TL7573 and TL8837 a weak signal was found using MEPCR/ASO without Mva1 digestion, while no signal was found for TL2308 (Fig. 1 and 2). Using MEPCR/ASO the signals for the parenchyma of TL7573 and TL8837 were intensified, while the mutation in TL2308 was now detectable. Since the parenchyma of TL7573 and TL8837 contained micro-invasive SE cells we cannot determine whether the $R A S$ mutation was only present in these $\mathrm{SE}$ cells or also in the CIS component. However, the findings for the parenchyma of 'TL2308, containing only CIS, indicate that $R A S$ mutations can occur in a noninvasive precursor lesion. No NRAS mutation was found in the parenchyma of TL3544 (not shown). Since only PCR/ASO was used to detect NRAS mutations, the presence of a mutation in the CIS cells cannot be excluded, in analogy to the findings for the parenchyma of TL2308.

The nature of the detected mutations is summarized in Table 1, showing identical base conversions in both the tumor and the adjacent parenchyma.

\section{DISCUSSION}

Since no HRAS mutations have been detected in TGGTs or derived cell lines (Mulder er al., 


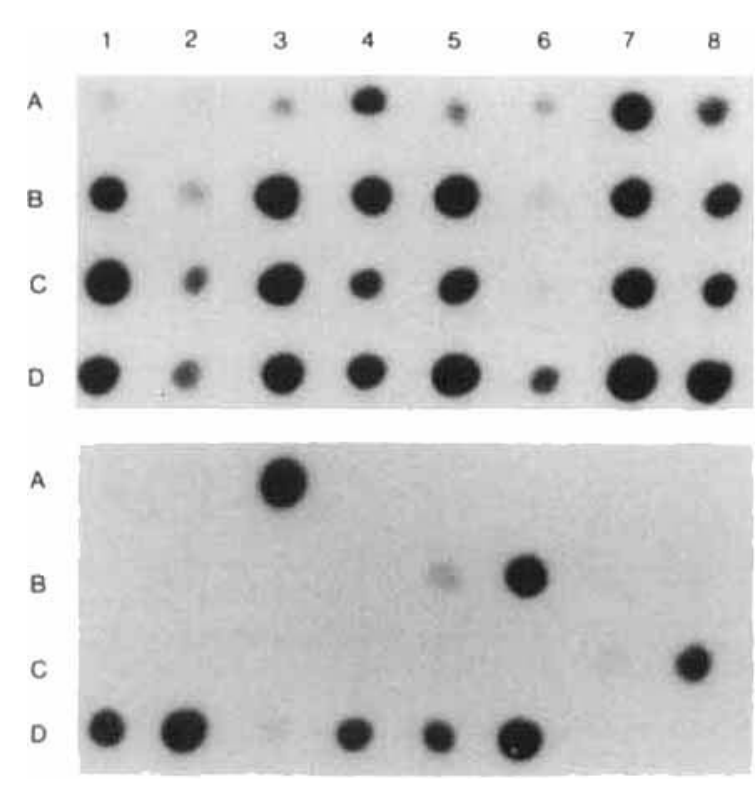

Figure 2. Example of dot blot analyses of mutant-enriched polymerase chain reaction products for detection of KRAS 12 mutants. The upper $A-D$ panel represents results using the wild-type specific probe, which detects GGT. The lower A-D panel represents results after hybridization with the probe specific for the CGT sequence. Both blots were exposed after washing at high stringency. The first six positions (Al-A6) represent the positive controls for all possible mutations of the first or second base of codon 12 ( $A 3$ corresponding with CGT). The remaining positions (A7, DB) are examples of testicular germ cell tumors, with paired signals from each tumor: without (left dot) and with Mval digestion (right dot) after the first amplification. For example: C7 (without digestion) and C8 (with digestion) = parenchyma of tumor TL7573, note the enhancement in signal intensity after Mval digestion using the mutant specific probe; B5 and B6 = tumor HT85; DI and D2 $=$ tumor TL7573; D3 and D4 = parenchyma of tumor TL8837; D5 and D6 = tumor TL8837.

1989; Dmitrovsky et al., 1990; Ganguly et al., 1990; Tesch et al., 1990; Moul et al., 1992; Ridanpää et al., 1993), we did not screen our samples for mutations in this gene. To analyse the incidence of $N$ - and KRAS codon 12, 13, and 61 mutations, the PCR/ASO was applied to 100 primary TGCTs, while all $40 \mathrm{SE}$ in this series were also subjected to MEPCR/ASO to detect mutations in $K R A S$ codon 12. Only six SE and one NS were found to contain a $R A S$ mutation. Six of these mutations (five in SE and one in NS) were already detected using PCR/ASO. Our data, showing an incidence of $K R A S$ mutations of $4 \%$, are concordant with those reported (Mulder et al., 1989; Ganguly et al., 1990; Moul et al., 1992; Ridanpää et al., 1993). Although using the same approach (frozen samples and conventional PCR/ASO), we did not find a high percentage of mutations in NRAS 12 and 61 , as reported by Ganguly et al. (1990). This could be due to difficulties in their interpretation of the mutation-specific hybridization signals.
TABLE I. Summary of the Nature of the $N-$ and KRAS

Codon 12 Mutations in Testicular Seminomas (SE) and Testicular Nonseminomatous Germ Cell Tumors (NS), and Their Adjacent Carcinoma In Situ Containing Parenchyma (P)

\begin{tabular}{|c|c|c|c|}
\hline Sample & Histology & $\begin{array}{l}\text { NRAS } 12 \\
\text { mutation }\end{array}$ & $\begin{array}{l}\text { KRAS } 12 \\
\text { mutation }\end{array}$ \\
\hline TL6/4 & SE & & $\begin{array}{l}\text { GGT } \rightarrow \text { GCT } \\
\text { gly } \rightarrow \text { ala }\end{array}$ \\
\hline TL1049 & SE & $\begin{array}{l}\text { GGT } \rightarrow \text { GAT } \\
\text { gly } \rightarrow \text { asp }\end{array}$ & \\
\hline TL2191 & SE & $\begin{array}{l}\text { GGT } \rightarrow \text { GAT } \\
\text { gly } \rightarrow \text { asp }\end{array}$ & \\
\hline TL.2308 & NS & & $\begin{array}{l}\text { GGT } \rightarrow \text { TGT } \\
\text { gly } \rightarrow \text { cys }\end{array}$ \\
\hline TL2308 & $P$ & & $\begin{array}{l}\text { GGT } \rightarrow \text { TGT } \\
\text { gly } \rightarrow \text { cys }\end{array}$ \\
\hline TL.3544 & SE & $\begin{array}{l}\text { GGT } \rightarrow \text { GCT } \\
\text { gly } \rightarrow \text { ala }\end{array}$ & \\
\hline TL7573 & SE & & $\begin{array}{l}\text { GGT } \rightarrow \text { CGT } \\
\text { gly } \rightarrow \text { arg }\end{array}$ \\
\hline TL7573 & $\mathbf{P}$ & & $\begin{array}{l}\text { GGT } \rightarrow \text { CGT } \\
\text { gly } \rightarrow \text { arg }\end{array}$ \\
\hline TL8837 & SE & & $\begin{array}{l}\text { GGT } \rightarrow \text { CGT } \\
\text { gly } \rightarrow \text { arg }\end{array}$ \\
\hline TL8837 & $\mathbf{P}$ & & $\begin{array}{l}\text { GGT } \rightarrow \text { CGT } \\
\text { gly } \rightarrow \text { arg }\end{array}$ \\
\hline
\end{tabular}

Taking into account the sensitivities of the two detection methods used (one mutant among 40 or one mutant among 10,000 wild type alleles for PCR/ASO and MEPCR/ASO, respectively), the minimal percentage of mutant alleles that needs to be present for detection can be calculated. A consistent overrepresentation of (parts of) $12 p$, on which KRAS is located, is found in TGCTs (De Jong et al., 1990; Oosterhuis et al., 1990; Rodriquez et al., 1993a,b), with a mean copy number of about six. Assuming the presence of one mutant (codon 12) and five wild type KRAS alleles per mutant tumor cell, at least $5.5 \%$ of the cells in a sample has to carry the mutant allele to allow detection with PCR/ASO, while $0.02 \%$ is needed using MEPCR/ASO. Our comparison of the conventional and mutant-enriched PCR based methods indicates that the low incidence of KRAS 12 mutations in TGCTs must be due to the absence of mutations in the samples studied, and not to the threshold of the PCR/ASO.

The study of flow-sorted SE nuclei by Mulder et al. (1989) showed NRAS mutations in four out of 14 cases. Three of these mutant tumors were studied for heterogeneity for the presence of mutant alleles 
between separate areas within one tumor. Two tumors were shown to be heterogeneous. Of the two KRAS mutant tumors, coded HT31 and HT85 in the study of Mulder et al. (1989), HT31 was also found to be heterogeneous. We confirmed the data on these $K R A S$ mutant $\mathrm{SE}$, which were analyzed in addition to the $40 \mathrm{SE}$ in our series, using MEPCR/ ASO (Fig. 2, only shown for HT85). Therefore, it cannot be excluded that tumor heterogeneity for $R A S$ mutations leads to underestimation of the incidence of these mutations.

A pathogenetic event can be considered of importance for tumor formation when it can be demonstrated in a high percentage of malignant cells within one tumor and in most independent tumors of the same histology. Taking together the results described here and those of Mulder et al. (1989), Moul et al. (1992), and Ridanpää et al. (1993), a total incidence of $R A S$ mutations in primary TGCTs of $11 \%$ is found, with $18 \%$ in SE and $4 \%$ in NS. Together with the heterogeneity for RAS mutations within a single tumor (Mulder et al., 1989), and the detection of a $R A S$ mutation in parenchyma containing CIS and not in the adjacent 'TGCTs (Moul et al., 1992), this supports the contention that $R A S$ mutations are not essential in the initiation or progression of TGCTs. However, a role of KRAS in the development of TGCTs by relative overrepresentation of (parts of) the short arm of chromosome 12 cannot be excluded. The difference between $\mathrm{SE}$ and NS concerning the incidence of mutations needs further investigation. The question whether mutations can already be present in noninvasive CIS, or only in the (micro-)invasive tumor, can be answered using microdissection of tissue sections of parenchyma under histological control to isolate CIS cells specifically.

Recently, Arends et al. (1993) reported on the suppression of apoptosis in rat fibroblast cell lines by mutant $H R A S$. In this context, it is interesting that in vitro culture analysis revealed a consistent difference between $14 \mathrm{SE}$ without and three with a $R A S$ mutation (Olie et al., in press). Using a coculture system with an embryonal fibroblast feeder, tumors TL1049, TL3544, and TL7573 (all associated with a strong hybridization signal in PCR/ASO) showed enhanced survival and proliferation. TL8837 and TL2191 were not available for in vitro culture. Frisch and Francis (1994) recently reported on the induction, and abrogation by $\mathrm{mu}-$ tant $H R A S$, of apoptosis by disruption of epithelial cell-matrix interactions. Since we have indications that SE cells also enter apoptosis immediately after isolation from their micro-environment (Olie et al., in preparation), suppression of apoptosis by mutant $R A S$ could explain the enhanced survival and proliferation in vitro of the mutant tumors. It is unlikely that dysfunction of other genes in the $R A S$ pathway, mimicking the effect of RAS mutations, are involved in the development of TGCTs, because of the absence of SE without RAS mutations which could be cultured in vitro. The possible tumor heterogeneity of the KRAS mutation in TL614, suggested by the presence of less than $5.5 \%$ mutant cells, and its relation to in vitro behavior will be studied.

$N$ - and $K R A S$ mutations indicate an unfavorable prognosis in childhood acute lymphocytic leukemia (Lübbert et al., 1990) and nonsmall cell lung cancer, especially adenocarcinoma (Slebos et al., 1990; Mitsudomi et al., 1991), respectively. In addition, an enhanced in vitro proliferative capacity is reported for adult acute myeloid leukemia with a poor prognosis (Löwenberg et al., 1993). In view of these and our findings we will investigate the prognostic relevance of RAS mutations in TGCTs.

\section{ACKNOWLEDGMENTS}

This work was supported by the Dutch Cancer Society (L.H.J.L. and J.W.O., grant DDHK 91-19 to R.A.O., and grant NKI 91-08 to L.B. and B.T.). We thank the collaborating pathologists and urologists in the southwestern part of the Netherlands for providing the tumor samples. Marian Burghouwt and Arie Kievit are acknowledged for technical assistance and printing the photos, respectively.

\section{REFERENCES}

Arends MJ, McGregor AH, Toft NJ, Brown EJH, Wyllic AH (1993) Susceptibility to apoptosis is differentially regulated by c-myc and mutated $\mathrm{Ha}$-ras oncogenes and is associated with endonuclease availability. Br J Cancer 68:1127-1133.

De Jong B, Oosterhuis JW, Castedo SMMJ, Vos A, Te Meerman GJ (1990) Pathogenesis of adult testicular germ cell tumors: A cytogenetic model. Cancer Genet Cytogenet 48:143-167.

Dmitrovsky E, Murty VVVS, Moy D, Miller WH, Jr., Nanus D, Albino AP, Samaniego F, Bosl G, Chaganti RSK (1990) Isochromosome $12 \mathrm{p}$ in non-seminoma cell lines: Karyologic amplification of c-ki-ras, without point-mutational activation. Oncogene 5:543548.

Frisch SM, Francis H (1994) Disruption of epithelial cell-matrix interactions induces apoptosis. J Cell Biol 124:619-626.

Ganguly S, Murty VV, Samaniego F, Reuter VE, Bosl GJ, Chaganti RS (1990) Detection of preferential NRAS mutations in human male germ cell tumors by the polymerase chain reaction. Genes Chromosom Cancer 1:228-232.

Kahn SM, Jiang W, Culbertson TA, Weinstein IB, Williams GM, Tomita N, Ronai $Z$ (1991) Rapid and sensitive nonradioactive detection of mutant K-ras genes via "enriched" PCR amplification. Oncogene 6:1079-1083.

Kumar R, Sukumar S. Barbacid M (1990) Activation of ras oncogenes preceding the onset of neoplasia. Science 248:1101-1104.

Löwenberg B, Van Putten WLJ, Touw IP, Delwel R, Santini V (1993) Autonomous proliferation of leukemic cells in vitro as a determinant of prognosis in adult acute myeloid leukemia. $\mathrm{N}$ Engl J Med 328:614-619.

Lübbert M, Mirro J, Miller CW, Kahan J, Isaac G, Kitchingman G, Mertelsmann R, Herrmann F, McCormick F, Koeffler HP (1990) 
N-Ras gene point mutations in childhood acute lymphocytic leukemia correlate with a poor prognosis. Blood 75:1163-1169.

Manjatis T, Fritsch EF, Sambrook J (1982) Isolation of high molecular-weight, eukaryotic DNA from cells grown in tissue culture. In: Molecular Cloning. New York: Cold Spring Harbor Laboratory, $\mathrm{p} 280$.

McCormick F (1993) How receptors turn Ras on. Nature 363:1516.

Mitsudomi T, Steinberg SM, Oie HK, Mulshine JL, Phelps R, Viallet J, Pass H, Minna JD, Gazdar AF (1991) Ras gene mutations in non-small cell lung cancers are associated with shortened survival irrespective of treatment intent. Cancer Res 51:49995002.

Mostofi FK, Sesterhenn IA, Davis CJJ (1987) Immunopathology of germ cell tumors of the testis. Sem Diagn Pathol 4:320-341.

Moul JW, Theune SM, Chang EH (1992) Detection of ras mutations in archival testicular germ cell tumors by polymerase chain reaction and oligonucleotide hybridization. Genes Chromosom Cancer 5: 109-118

Mulder MP, Keijzer W, Verkerk A, Boot AJM, Prins MEF, Splinter TAW, Bos JL (1989) Activated ras genes in human seminoma: Evidence for tumor heterogeneiry. Oncogene 4:1345-1351.

Olie RA, Looijenga L.HJ, Dekker MC, De Jong FH, Van DisselEmiliani, De Rooij DG, Van der Holt B, Oosterhuis JW (in press) Heterogeneity in the in vitro survival and proliferation of human scminoma cells. Brit. J. Cancer.

Oosterhuis JW, Castedo SMMJ, De Jong B, Cornelisse CJ, Dam A, Sleijfer DT, Schraffordt Koops H (1989) Ploidy of primary gern cell tumors of the testis. Pathogenetic and clinical relevance. Lab Invest 60:14-20.

Oosterhuis JW, Castedo SMMJ, De Jong B (1990) Cytogenetics, ploidy and differentiation of human testicular, ovarian and extragonadal germ cell tumours. Cancer Surv 9:321-332.

Oudejans JJ, Slebos RJC, Zoetmulder FAN, Mooi WJ, Rodenhuis $S$ (1991) Differential activation of RAS genes by point mutation in human colon cancer with metastases to either lung or liver. Int J Cancer 49:875-879.

Ridanpää $M$, Lothe RA, Onfelt A, Fosså S, Borresen AL, Husgafvel-Pusiainen $K$ (1993) K-ras oncogene codon 12 point mutations in testicular cancer. Environ Health Perspect 101(Suppl 3): $185-187$.

Rodenhuis S (1992) Ras and human tumors. Semin Cancer Biol $3: 241-247$.

Rodriquez E, Houldsworth J, Reuter VE, Meltzer P, Zhang J. Trent JM, Bosl GJ, Chaganti RSK (1993a) Molecular cytogenetic analysis of $\mathrm{i}(12 \mathrm{p})$-negative human male germ cell tumors. Genes Chromosom Cancer 8:230-236.

Rodriquez E, Mathew S, Reuter V, Ilson DH, Bosl (jJ. Chaganti RSK (1993b) Cytogenetic analysis of 124 prospectively ascerrained male germ cell tumors. Cancer Res 52:2285-2291.

Skakkebak NE, Berthelsen JG, Giwercman A, Mueller J (1987) Carcinoma-in-situ of the testis: Possible origin from gonocytes and precursor from all types of germ cell tumors except spermatocytoma. Int J Androl 10:19-28.

Slebos RJC, Kibbelaar RE, Dalesio O, Kooistra A, Stam J, Meijer CJLM, Wagenaar SjSc, Vanderschueren RGJRA, van Zandwijk N, Mooi WJ, Bos JL, Rodenhuis S (1990) K-ras oncogene activation as a prognostic marker in adenocarcinoma of the lung. $N$ Engl J Med 323:561-565.

Slebos RJC, Bocrrigter L, Evers SG, Wisman P, Mooi W], Rodenhuis $S$ (1992) A rapid and simple procedure for the routine detection of ras point mutations in formalin-fixed, paraffin-embedded tissues. Diagn Mol Pathol 1:136-141.

Tesch H, Fürbass R, Casper J, Lyons ], Bartram CR, Schmoll HJ, Bronson DL (1990) Cellular oncogenes in human teratocarcinoma cell lines. Int J Androl 13:377-388.

Verlaan-De Vrics M, Bogaard ME, Elst H, van Boom JH, van der Eb AJ, Bos JL (1986) A dot-blot screening procedure for mutated ras oncogenes using synthetic oligodeoxynucleotides. Gene 50: $313-320$. 